\title{
Impact of Vamana dhauti in Amalapitta: A Critical Review
}

\author{
Rekha BV, Chaudhari Krishnakumari Balvantbhai*
}

\section{Rekha BV, Chaudhari Krishnakumari Balvantbhai*}

Department of Swasthavritta, Government Ayurveda Medical College, Mysuru, Karnataka, INDIA.

\section{Correspondence}

Dr. Chaudhari Krishnakumari Balvantbhai

$2^{\text {nd }}$ Year Pg Scholar, Department of Swasthavritta, Government Ayurveda Medical College, Mysuru-560010, Karnataka, INDIA.

Email: krishnachaudhari2680@gmail.com History

- Submission Date: 05-11-2021

- Revised Date: 27-12-2021

- Accepted Date: 13-01-2022

DOI : 10.5530/ijmedph.2022.1.2

Article Available online

http://www.ijmedph.org/v12/i1

\section{Copyright}

(C) 2022 Phcog.Net. This is an openaccess article distributed under the terms of the Creative Commons Attribution 4.0 International license.

\begin{abstract}
"Amlapitta" is one of the most common lifestyle disorder which leads to many complication like ulcer, gastritis, anemia, IBS, and malabsorption etc. The burden of lifestyle disorders is rapidly increasing worldwide. In spite of many available drugs in market there is no significance reduction in the prevalence and Incidence of this illness which remarkably emphasis on the need of novel approaches in combating those illnesses. Ayurveda and Yoga an Ancient system of medicine which gives importance for Shodanakarma (purificatory processes) for diasese free life. In Yoga shastra, Shatkarma is mentioned for purification, Vamana dhauti is one of them. Vamana dhauti is a type of Antar dhauti. Which removes Kapha and pitta from stomach and helps in breaking the pathology of amlapitta.

Key words: Amlapitta, Vamanadhauti, Shadkarma, Kunjalakriya, Gastritis.
\end{abstract}

\section{INTRODUCTION}

Changing in environment and lifestyle has leds to different diseases one among them is amlapitta, amlapitta related to annavaha srothas and various research shows that the eattind of viruddha ahara (incommpatable food) will cause agnimandya and there by ajjeerna which is root cause for all the diseases. According to the Center for Disease Control and Prevention (CDC), more than 72 million adults are suffering from GERD and no state has a GERD rate less than $15 \%$ - the national goal. It also leads many complication like ulcer, gastritis, anemia, IBS, and malabsorption etc In spite of many available drugs in market there is no significance reduction in the prevalence and incidence of this illness which remarkably emphasis on the need of novel approaches in combating those illnesses.

\section{Etymology of Word Amlapitta}

The word Amlapitta made up of two words,

"Amla" + "Pitta"

\section{DEFINITION OF AMLAPITTA}

Chakrapani has defined Amlapitta as "Amlapittam cheti amlagounodriktam pittam". Amlapitta is a condition in which Amla Guna of Pitta is increased. According to Kashyapa, Vidagdha Annarasa staying in Aamashaya attains Shuktata and produces Amlapitta. ${ }^{2}$

\section{NIDANA OF AMLAPITTA}

Nidana pertaining to Amlapitta are explained in the different classics, which can be summarized under three headings,

Ahara sambhandi, Vihara sambhandi, Anya (includes kala, desha, manasika vikaras etc.) Table 1.

\section{SAMPRAPTI OF AMLAPITTA ${ }^{6,7}$}

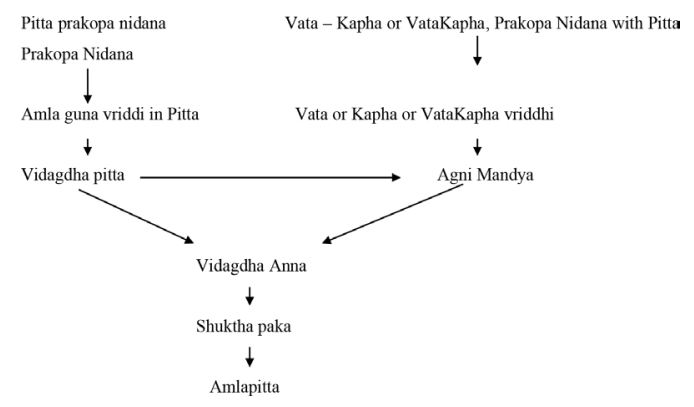

\section{POORVAROOPA OF AMLAPITTA}

The poorvarupa of Amlapitta are not explained in the classics. Still however the Alpamatra of Roopa may be considered here as the poorvarupa of Amlapitta Table 2, Roopa of Amlapitta in Table 3.

\section{BHEDAS OF AMLAPITTA}

Two types: ${ }^{10}$

1. Urdhvaga Amlapitta

2. Adhoga Amlapitta

According to Acharya Kashyapa and Madhava Table 4 .

\section{VAMANA DHAUTI REVIEW}

Shatkarma are 6 major procedures explained by yoga shastra for cleaning of the body these are the pre requisite for doing pranayama. Vamana dhauti one among them to remove toxins and promote proper digestion. This procedure is practiced early in the morning in empty stomavh for cleaning GI track it is done by drinking lucke warm saline (Akanta pana).
Cite this article : Rekha BV, Balvantbhai CK. Impact of Vamana dhauti in Amalapitta: A Critical Review. Int J Med Public Health. 2022;12(1):8-11. 
Table 1: Nidana of Amlapitta. ${ }^{3-5}$

\begin{tabular}{|c|c|c|c|}
\hline \multicolumn{2}{|c|}{ Aharaja } & Viharaja & Anyaja \\
\hline Abhojana & Ikshuvikara & Bhukte bukte snana & Manasika \\
\hline Atibhojana Ajeerna & atisevana Ushna & Bhukte bukte & Chinta \\
Amapurana & rasa atisevana & avagaha Bhukte & Shoka \\
Vishamashansana & Drava atisevana & bukte divaswapa & Krodha \\
atisevana Katurasa & Kulattha atisevana & Vegadharana & Bhaya \\
atisevana Amla & Madya atisevana & & KALAJA \\
Adhyasana & Ruksha atisevana & & Varsha \\
Gurubhojana & Bhrustadhanya & & Pravrut \\
Gorasatisevana & atisevana & & \\
\hline Phanita-atisevana & & & \\
Pishta-atisevana & & & \\
\hline
\end{tabular}

Table 2: Roopa of Amlapitta. ${ }^{8}$

\begin{tabular}{c|c|c}
\hline Avipaka & Tiktodgara & Hriddaha \\
\hline Klama & Amlodgara & Kanthadaha \\
\hline Utklesha & Gaurava & Aruchi \\
\hline
\end{tabular}

Table 3: Vishistha Rupa.9

\begin{tabular}{|c|c|c|}
\hline Vataja & Pittaja & Kaphaja \\
\hline Shoola & Bhramaha & Shareera guruta \\
\hline $\begin{array}{c}\text { Angasada } \\
\text { Jrumbha }\end{array}$ & Vidaha & Chardi \\
\hline
\end{tabular}

Table 4: Bheda on amlapitta. ${ }^{11}$

\begin{tabular}{|c|c|}
\hline Kashyapa & Madhava \\
\hline Vatika Amlapitta & Sanila Amlapitta \\
Paittika Amlapitta & Sanila Kapha Amlapitta \\
Slesmika Amlapitta & Sakapha Amlapitta \\
& Slesmapitta Amlapitta \\
\hline
\end{tabular}

Upashaya Anupashaya

Upashaya and anupashaya according to Kashyapa Table 5.

\begin{tabular}{|c|c|}
\hline Vataja & Snigdha Upashaya \\
\hline Pittaja & Mahura and Sita Upashaya \\
\hline Kaphaja & Ruksha and Ushna Upashaya \\
\hline
\end{tabular}

\section{TERMINOLOGY}

Vamana dahauti made of two words vamana means vomiting - eject matter from the stomach, dhauti means to cleanse. It is also known as kunjala kriya because water forcefulle expelled from stomach just like elephant spray water from trunk. ${ }^{15}$

\section{Vamana dhauti procedure}

a) Purva Karma.

b) Pradhana Karma.

c) Paschat Karma.

\section{a. Purva Karma}

Time of the procedure: early in the morning in empty stomach. ${ }^{16}$
Systemic and local examination of the patient.

Preparation of the Vamana dhauti Dravya.

3-4 liters of lukewarm water, Tamra patra. ${ }^{17}$

\section{Method of preparation of Vamana Dravya}

Take 3- 4 Liters of water and boil it well, add salt to the water in a proportion of one teaspoonful per liter of water. Stir well and keep in separate jar for drinking. We recommend that the water be lukewarm as of body temperature..$^{18,19}$

\section{b. Pradhana Karma}

After examination, the patient is made to sit on the chair in a comfortable posture. Asked the patient to drink the Vamana dhauti Dravya i.e. the warm salted water. Until he feels the stomach and throat is full.

\section{POSTURE}

Sit in the chair comfortably with back bend forward so that vomiting becomes easier.

\section{PROCESS OF VAMAN DHAUTI}

Subject is made to drink water continuously, uninterruptedly until the stomach is full and can no more take a single drop of water further then given one more glass. This may be a little difficult but it is essential to fill the stomach as fully as possible. Under these circumstances the urge to throw out the water from the stomach hardly needs to be stimulated, it may even occur spontaneously. 6 medium sized glasses (300ML) of water are about the average number required to fill the stomach. Then from a standing position bend forwards to any container dedicated to collect vomitus. Make sure the trunk is as horizontal as possible. Then open your mouth as wide as possible. This should induce the water to suddenly and effortless. Gush out from the stomach. Continue in this way until there is no more water in the stomach. This is indicated when tickling the back of the throat does not bring up any more water. Now it completes the vamanadhauti procedure.

\section{c. Paschat Karma}

Patient is adviced to face wash, Kavala, and Gandusha with lukewarm water and Rapid exhalation to remove the water remaining in the GI tract, then rest in Shavasana.

\section{CONTRAINDICATION}

Most people can do this practice but it is contraindicated in hernia, Hypertension, CVD Cardiovascular diseases, Headache (migraine, Tension headache, cluster headache etc.) Epilepsy, recent surgeries, pregnancy and menstruation. ${ }^{21}$

\section{DISCUSSION}

ROLE OF NIDANAPANCHAKA AS A DIAGNOSTIC TOOL IN AMLAPITTA

\section{PROBABLE MODE OF ACTION OF VAMANDHAUTI KARMA}

Amlapitta is maily due to pitta dosha, acharya madhava has narreted all the teatment modalities aiming towrds maintaining equilibirium 


\section{ANALAYSIS OF NIDANA TABLE 6}

Table 6: Analaysis of Nidana.

\begin{tabular}{|c|c|}
\hline Vata Prakopa & $\begin{array}{c}\text { Vegadharana (suppression of natural urges), Ruksha } \\
\text { Atisevana }\end{array}$ \\
\hline Pitta prakopa & $\begin{array}{c}\text { Usha Atisevana, Drava- Atisevana, Kulatha Atisevana, } \\
\text { Katu-Amla Rasa Atisevana }\end{array}$ \\
\hline Kapha prakopa & $\begin{array}{c}\text { Adhyashana, Gurubhojana, Ikhuvikara Atisevana, } \\
\text { Bhukte Bhukte Diwaswapna }\end{array}$ \\
\hline Pitta Kapha Prakopa & Madhya Atisevana \\
\hline Kapha pitta prakopa & $\begin{array}{c}\text { Pishta Atisevana, Bhukte Bhukte Snana, Bhukte } \\
\text { Bhukte Avagaha }\end{array}$ \\
\hline Tridosha prakopa & Phanita Atisevana, Virrudha, Vishamashana \\
\hline Agnimandya & $\begin{array}{c}\text { Ajeerna, Amapurana, Adhyashana, Atibhojana, } \\
\text { Vishamashana }\end{array}$ \\
\hline Srotas & $\begin{array}{c}\text { Purishvaha Srotas - Ajeerna, Adhyashana, } \\
\text { Vegadharana } \\
\text { Annava Srotas - Atibhojana }\end{array}$ \\
\hline
\end{tabular}

\section{ANALAYSIS OF LAKSHNA TABLE 7}

Table 7: Analysis of Lakshna.

Vata Vidbheda, Shiroruja, Hritshula, Adhmana Antrakujana, Romaharsha

Pitta Amlaudgara, Kantadha, Hritdaha, Utklesha

Kapha Gaurava, Angasada, Gurukoshtata

Srotas Avipaka, Aruchi

\section{SAMPRAPTI CORRELATION WITH SHAD KRIYAKALA}

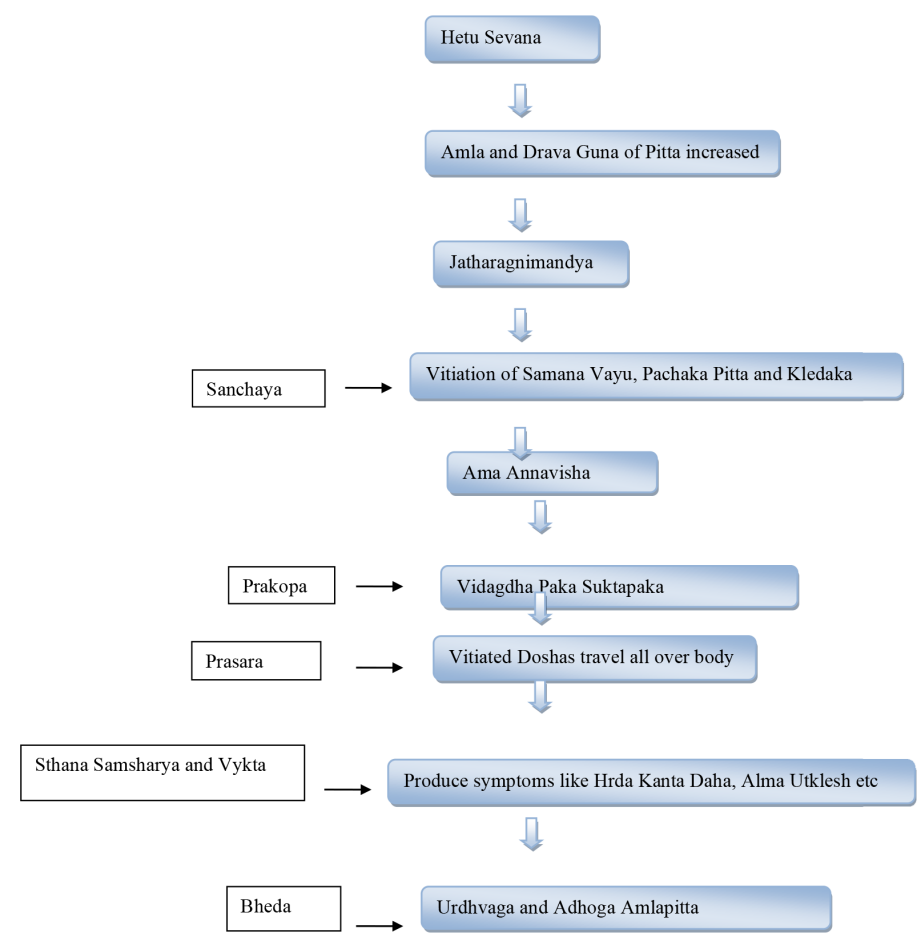

UPASHAYA IN AMLAPITTA TABLE 8

\begin{tabular}{|c|c|c|}
\hline TYPES OF AMLAPITTA & UPASAYA & EXAMPLE \\
\hline Vataja & Snigdha Upashaya & Ksheera \\
\hline Pittaja & Madhura and Sita Upashaya & Yastimadhu Ghrita \\
\hline Kaphaja & Ruksha and Ushna Upashaya & Sunthi \\
\hline
\end{tabular}

of kapha and pitta dosha, to achive the same vamandhouti is the best. Vamandhauti mainly acts on Amashaya and Annavaha Srotasa. It neutralizes the acid balance in stomach thus helpful in counteracting Tivra Jatharagni., Salt water- helps in osmosis removes toxins from cells. And also help in liquification of Achadita and Avalipta Dhatugata Ama. Suddhikriya resulting in metabolism. In this way Vamana dhauti is the best possible helps to maintain the homeostasis of the stomach through its cleansing effect.

\section{CONCLUSION}

The Vamana dhauti is best possible technique of cleansing and removal of toxins of the upper GI track. Vamana dhauti is the simple processor which cleans stomach very effectively without much diatic rule as in vamana. Impact of Vamana dhauti is all most equal to vamana with all the benefits of shodhana kriya thus it prevents all the diseases which produced by indigestion. Cannot change your food habits and certainly cannot remove mental and emotional tension. And hence in the current global crisis of lifestyle disorder, practice of Vamanadhauti can give a major breakthrough by preventing most of the complication of Amalpitta and suppressing it in rudimentary stage.

\section{ACKNOWLEDGEMENT}

The authors will extends heartfelt thanks to the editorial team, technical team of IJMEDPH for their rapid response in publishing the article.

Authors will also extends cordial gratitude to principal and all teaching staff of Department of Swasthavritta, Mysuru

\section{CONFLICT OF INTEREST}

The authors declare that there is no conflict of interest.

\section{REFERENCES}

1. Acharya YT. editor, chapter 15 , verse $45-49$ (teeka). Varansi; chaukhambha orient aliya. In: Agnivesha, Ayurvedadipika commentary of sri Chakrapanidatta on Charaka Samhita of Agnivesha, Chikitsa sthana; Grahani Chikitsitam. Vol. 2019; 2019;517.

2. Hemraj Sharma Pandit, chapter 16/7-9 [reprint. p. 2009]. Vruddhajivakiya Tantra, kashyapa Samhita. In: Varanasi chowkhmbha Sanskrit samsthan, kila sthana, P.-336.

3. Satyapala. In: Bhisagacharya, editor Kashyapa Samhita of Vrddha Jivaka revised by Vatsya with Sanskrit introduction by Pandit Hemaraja Sharma, Khila Sthana, 16/3-6. reprint ed. Varanasi: Chaukhambha Sanskrit Sansthan; 2009:335.

4. Dr. Tripathy Bramhananda ed. Madhava Nidanam of Madhavakara with Madhukosha commentary by Vijayarakshita and Shrikantadatta vol. reprint ed. Vol. II(51/1). Varanasi: Chaukhambha Surabharati Prakashana; 2003:225.

5. Pandit Sri Bhisagratna, Misra Bramha Sankara ed. Bhava Prakash of Sri Bhavamishra, Uttarardha (part 2). Madhya khanda, 10/1. $9^{\text {th }}$ ed 2005. Varanasi: Chaukhambha Sanskrit Bhawana, pp 121.

6. Satyapala. In: Bhisagacharya, editor Kashyapa Samhita of Vrddha Jivaka revised by Vatsya with Sanskrit introduction by Pandit Hemaraja Sharma, Khila Sthana, 16/7-9. Reprint ed. Varanasi: Chaukhambha Sanskrit Sansthan; 2009:335.

7. Dr. Tripathy Bramhananda ed. Madhava Nidanam of Madhavakara with Madhukosha commentary by Vijayarakshita and Shrikantadatta vol. reprint ed. Vol. II, 51/1-2. Varanasi: Chaukhambha Surabharati Prakashana; 2003:225.

8. Madhavakara, Madhava Nidana Part 2nd. With Madhukosha Sanskrit commentary by Sri Sudarshan Sastri. 13th ed. Varanasi: Chaukhamba Sanskrit 
Sansthan; 2001;51/1-2

9. Jivaka Vruddha, Samhita Kashyapa. With Sanskrit introduction by Pandit Hemraj Sharma. Varanasi: Chaukhamba Sanskrit Sansthan; 2006:16/7-10.

10. Madhavakara, Madhava Nidana Part $2^{\text {nd }}$. With Madhukosha Sanskrit commentary by Sri Sudarshan Sastri. 13 th ed. Varanasi: Chaukhamba Sanskrit Sansthan; 2001;51/3-4.

11. Jivaka Vruddha, Samhita Kashyapa. With Sanskrit introduction by Pandit Hemraj Sharma. Varanasi: Chaukhamba Sanskrit Sansthan; 2006;16/16-17.

12. Jivaka Vruddha, Samhita Kashyapa. With Sanskrit introduction by Pandit Hemraj Sharma. Varanasi: Chaukhamba Sanskrit Sansthan; 2006;16/16-17.

13. Available from: https://moonladyyoga.wordpress.com/2012/02/12/hatha-yoga- kunjal-kriya-by-swami-satyananda-saraswati/ [cited 5/1/2022].

14. Svami Niranjanananda Sarsavati, Gheranda Samhita, Varansi, Bhusan Press, Shat Karma; Chapter 1, verse 38-39. 1st ed; 1997:68.

15. Samagandi Vaidya Kashinath, Svasthavrttamrutam. Jaipur, Ayurved Sanskrit Hindi Pustak Bhandar, Sata karma. 1st ed; 2019:303.

16. Saraswati Swami Satyananda. A Systematic course in the ancient tantric techniques of Yoga and kriya. Vol. 104

17. Dr. Prashanth Shetty Naturopathy and Yoga for Wellness and healing. Vol. 63

18. Samagandi Vaidya Kashinath, Svasthavrttamrutam. Jaipur, Ayurved Sanskrit Hindi Pustak Bhandar, Sata karma. 1st ed; 2019:305.

Cite this article : Rekha BV, Krishnakumari BC. Impact of Vamana dhauti in Amalapitta: A Critical Review. Int J Med Public Health. 2022;12(1):8-11. 